\title{
Relationship Between Job Satisfaction And Firm's Death
}

\author{
Montserrat Manzaneque Lizano, University of Castilla-La Mancha, Spain
} Regino Banegas Ochovo, University of Castilla-La Mancha, Spain

Alba Maria Priego de la Cruz, University of Castilla-La Mancha, Spain

\begin{abstract}
This paper verifies empirically the link between employee job satisfaction and the rate of failure, understood as cessation of activity. The authors examine a sample of nine industrial sectors during the period 2007-2010. The results show that job satisfaction reduces the failure rate in the business sector and they highlight the importance of employees' attitudes regarding working conditions, especially in difficult economic and financial situations.
\end{abstract}

Keywords: Job Satisfaction; Business Failure; Stakeholders Theory

\section{INTRODUCTION}

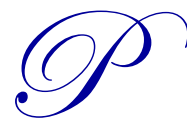

revious studies have revealed numerous explanatory variables able to anticipate or predict a future business failure, especially quantitative information extracted from the financial statements (Altman, 1984; Beaver, 1966). However, the events in recent years have shown the importance of the study on the stakeholders' dependence on the company, although very few studies have provided empirical evidence of its influence on business failure, demonstrating the need for progress in this field of research (Kane et al., 2005; Keasey \& Watson, 1991; Pajunen, 2006). Authors such as Argenti (1976), Keasey and Watson (1991), Ooghe and Waeyaert (2004), Kane, Velury and Ruf (2005) and Pajunen (2006) have shown the importance of other stakeholders' dependency on the firms. These studies suggest that if the company maintains satisfying relationships with stakeholders, it can achieve certain benefits that will impact positively on their performance, reducing your chances of failure in crisis situations. In this sense, a good relationship between firm and stakeholders benefits a normal and harmonious activity since, for example, the employees work harder, increasing the productivity (Dutton et al., 1994).

The employees, their skills, knowledge and experience to develop the firm objective make key their participation in the production process (Fernández, 1997). Indeed, a firm-employee successful relationship, as a corporate resource that promotes economic and social performance, increase productivity and competitiveness of firms. Also, it gives to firms the possibility to obtain temporary concessions to renegotiate the terms of employment contracts (Kane, et al., 2005).

According to this perspective, the problem lies in whether the relationship between the company and its employees can be a key factor and effective to detect the possibility of incurring a critical situation. So, the aim of this paper is to test empirically the link between company-employee relationship and the likelihood of incurring a failure situation, understood as the firm closure or "firm death".

The results show that job satisfaction, defined according to the hours worked and flextime, wages and other non-wage compensation, job security, training and promotion chances and social dialogue, reduces the failure rate of business sector, and thus they highlight the need to control the firm-employee relationship as a useful tool to achieve the commitment of future collaborations that avoid business failure.

These results are useful for researchers and business managers because it highlights the importance of the human factor and their attitude regarding working conditions for the survival of businesses in difficult economic and financial situations. 


\section{The Firm-Employee Relationship (Job Satisfaction) And Business Failure}

According to the company's resource-based view (RBV), the company has the ability to create value in terms of resources and capabilities through control of its relationship with stakeholders (management, employees, customers, suppliers, financial institutions, general public, and so on). So, a good relationship between managers and employees would be an opportunity to achieve advantages when a difficult economic and financial situation arises.

Among other things, the employee's set of skills is an inimitable and irreplaceable resource which, over time, gives sustainable competitive advantage to the firm, resulting in increased business performance (Choi \& Wang, 2009). In this sense, the retention of qualified employees improves productivity and encourages its link with business objectives, avoiding certain behaviors, such as strikes, boycotts, and so on. Also, it is a unique and inimitable resource that gives better firm reputation, positively affecting the positioning of the latter on the market and therefore its performance (Hendriks, 2008; Ruf et al., 2001). In addition, a good relationship between managers and employees plays an essential role in the processes of business failure because it gives to the firm the ability to achieve certain concessions (wage cuts, reduced overtime, reduced allowances, and so on) and leads employees to develop certain favorable attitudes (willingness to compromise, lack of interest in the call for strikes or strikes, efforts to improve productivity, and so on) that promote the recovery of a firm in adverse economic and financial conditions (Jones, 1995). Otherwise, the lack of a good relationship between managers and employees could contribute to the deterioration of the company (Zatzick \& Iverson, 2006). As an example, the necessary restructuration of a firm in difficulty could concern negatively the morality of the employee or his level of commitment, contributing to the demotivation and escape of the employees with more talent, as revealed in Greenhalgh (1983), Sutton et al. (1986) and Hardy (1987). In the long term, this situation can unleash, in turn, a fall in sales, exacerbating the financial problems of the company. However, if there was a good relationship between manager and employee, these adverse effects would be minimized.

In this regard, and from a theoretical point of view, Kane et al. (2005) describe two types of benefits derived from the relations of communication or of integration that supports the company with his employees:

1. Unconditional benefits: Satisfactory relations with the employees increase the productivity of the firms and diminish the costs of contracting, independently of the economic situation that is given in the environment that surrounds the company.

2. Conditional benefits: Good relations with the employees can be seen as a way to obtain a financial option, which only will be realizable if economic adverse conditions arise. In this respect, there are, a priori, reasons to think that the good relations between firms and their employees might avoid the insolvency. For example, it could facilitate the renegotiation of the terms of the labor contracts, to manage to obtain temporary concessions that relieve the problems of insolvency of a failed firm, improving with it the margin of profitability by cost reduction and reducing, in the last instance, the risk of financial insolvency.

Consistent with these theoretical perspectives, previous literature has reflected the importance of the relationship between employee satisfaction and performance, productivity and corporate profits (Davis \& Newstrom, 1999; Hackman \& Oldham, 1980), the stability of the organization (Organ \& Ryan, 1995), flexibility to its production processes, and the increase their ability to expand their market share.

\section{Econometric Specification And Results}

To achieve the objectives of this research, an analysis of mean differences with panel data has been conducted. As cross-sectional units, nine sectors for the Spanish context have been selected and data have been obtained for the period 2007-2010.

Following authors Chen and Williams (1999), Liu (2004) and Campbell et al. (2012), a macroeconomic perspective has been adopted to try to answer the research questions. So, the rate of business failure has been measured as the number of dead companies in a given sector (closure or cessation of activity) to the total number of those present in the same. 


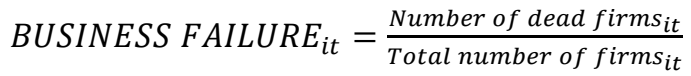

where "i" represents the activity sector and " $\mathrm{t}$ " is the time period considered. The data for the variables calculation are taken from the Central Business Directory published by the National Statistics Institute (DIRCE).

Also, according to the theoretical approaches, five dimensions of job satisfaction - working hours and flexible working hours, wages and other perquisites, job security, training and the promotion chances, employee satisfaction with social dialogue - are related to the perception that workers have of their jobs. Thus, it has adopted a subjective view of the quality of employment, called "job satisfaction" $\left(\operatorname{Sat}_{i t}\right)$, based on the view given by respondents for the $\mathrm{ECVT}^{1}$ about these five dimensions.

The satisfaction rate was obtained as the average of the dimensions (Iglesias, et al., 2011):

$S a t_{i t}=\frac{H_{i t}+W_{i t}+J S_{i t}+T P_{i t}+S D_{i t}}{5}$

where $\mathrm{Sat}_{\mathrm{it}}$ is average level of job satisfaction for sector $\mathrm{i}$ in period $\mathrm{t}, \mathrm{H}_{i t}$ is job satisfaction with hours worked and time flexibility of sector $\mathrm{i}$ in period $\mathrm{t}, \mathrm{W}_{\mathrm{it}}$ is job satisfaction with wages and other perquisites of sector $\mathrm{i}$ in period $\mathrm{t}$, JSit is job satisfaction with job security of sector i in period t, TPit is job satisfaction with training and promotion chances of sector $\mathrm{i}$ in period $\mathrm{t}$, and SDit is job satisfaction with social dialogue of sector $\mathrm{i}$ in period $\mathrm{t}$.

Table 1 presents the descriptive statistics of the variables considered.

Table 1: Mean Differences Between Companies Above And Below The Mean Failure

\begin{tabular}{|c|c|c|c|c|}
\hline $\begin{array}{l}\text { Dimension, Variables } \\
\text { \& Control Variables }\end{array}$ & $\begin{array}{c}\text { Mean Failure Rate }>0.10 \\
(\mathrm{~N}=12) 1\end{array}$ & $\begin{array}{c}\text { Mean Failure Rate } \leq 0.10 \\
(\mathrm{~N}=24) 0\end{array}$ & $\begin{array}{c}\text { Mean } \\
\text { Differences }\end{array}$ & $\begin{array}{c}\text { Test Univariate } \\
\text { (Sig.) }\end{array}$ \\
\hline SAT & 6.05 & 6.32 & 0.27 & $2.85 * * *$ \\
\hline $\mathrm{H}$ & 6.60 & 6.86 & 0.25 & $3.41 * * *$ \\
\hline $\mathrm{W}$ & 4.36 & 4.67 & 0.31 & $1.80 *$ \\
\hline JS & 7.14 & 7.33 & 0.19 & $2.07 * *$ \\
\hline $\mathrm{TP}$ & 6.51 & 7.10 & 0.59 & $4.78 * * *$ \\
\hline SD & 5.63 & 5.63 & 0.00 & 0.02 \\
\hline H1 & 6.85 & 7.12 & 0.27 & $3.32 * * *$ \\
\hline $\mathrm{H} 2$ & 6.39 & 6.40 & 0.01 & 0.11 \\
\hline H3 & 6.48 & 6.54 & 0.07 & 0.67 \\
\hline $\mathrm{H} 4$ & 6.70 & 7.36 & 0.66 & $4.36 * * *$ \\
\hline W1 & 5.91 & 6.04 & 0.12 & 1.06 \\
\hline W2 & 2.79 & 3.30 & 0.51 & $1.98 * *$ \\
\hline JS1 & 6.89 & 7.28 & 0.39 & $2.68 * *$ \\
\hline JS2 & 7.39 & 7.38 & -0.00 & -0.12 \\
\hline TP1 & 5.26 & 6.41 & 1.15 & $4.68 * * *$ \\
\hline TP2 & 7.76 & 7.79 & 0.03 & 0.37 \\
\hline SD1 & 5.63 & 5.63 & 0.00 & 0.02 \\
\hline
\end{tabular}

Source: Own elaboration. * Significant at $10 \%$ level of significance; ** Significant at $5 \%$ level of significance; *** Significant at $1 \%$ level of significance. Variable descriptions: SAT: Satisfaction with working hours and flexible hours; H: Satisfaction with salary and other remuneration-extra wages; JS: Satisfaction with job security; TP: Satisfaction with training, promotion, probabilities employees; SD: Satisfaction with social dialogue; H1: Satisfaction with the working conditions; H2: Satisfaction with flexible hours; H3: satisfaction with time off during the day; H4: Satisfaction with holidays and leave; W1: Satisfaction with salary; W2: Satisfaction with social support; JS1: Satisfaction with job tenure; JS2: Satisfaction with health and safety in the workplace; TP1: Satisfaction with academic training; TP2: Satisfaction with usefulness of the training received by the company in relation to the work they do; SD1: Satisfaction with their collective agreement or the Statute of Workers' Rights.

\footnotetext{
${ }^{1}$ This survey is produced annually and is based on a three-stage stratified sampling by autonomous region and municipality size. The sample comprised 6,020 aged 16 and older and living in Spain. See http://www.empleo.gob.es/estadisticas/ecvt/Ecvt2010/ ANE/Metodologia.htm for more details (Consulted: October 10, 2012).
} 
The data have been taken from nine sectors of activity (industry; construction; trade and repair; hotel and catering business; transport, storage and communications; real estate agencies, rents and managerial services; education; sanitary, veterinary activities and social services; as well as other social activities and personal services) during the sample period 2007-2010. Additionally, two groups have been defined in order to observe the differences between them for the variables defined, those with higher business failure rates than average, and those with business failure rates less than or equal to the average (see Table 1).

Thus, and as shown in Table 1, the job satisfaction is higher in sectors with failure rates less than or equal to the average, as the authors predicted. Also, this is manifested in the dimensions that define the satisfaction index. All, except satisfaction with the collective agreement, have higher than average levels in sectors with low failure rates. As for the variables, satisfaction with working hours, holidays and days off, social assistance, stability in the job, and training are higher in industrial sectors with a lower average level of business failure.

These figures confirm the approaches developed in this work, showing a negative relationship between job satisfaction and the business failure rate.

\section{CONCLUSION}

The defined index shows a negative relationship with the probability of business failure. Specifically, the results of this study show that:

- $\quad$ Employee satisfaction with working hours and flexible hours, wages and perquisites, job security and training reduces the level of business failure risk of activity of the company in a given sector and, therefore, these issues should capture the interest of business managers to ensure the cooperation of workers before a potential crisis.

- The relationship between job satisfaction and business failure is also a sectoral issue so that the sectors in which workers are more satisfied with their working conditions have a lower risk of failure treated as cessation of activity or firm death.

These results are especially useful for researchers and business managers because they emphasize the importance of the attitude of workers and job satisfaction information on survival of companies that are in an economic and financial difficulty situation.

\section{AUTHOR INFORMATION}

Montserrat Manzaneque Lizano is a Lecturer of Accounting in the Faculty of Social Sciences at the University of Castilla-La Mancha (UCLM). She completed her degree in Business in 2000 and earned her Ph.D. in Business Administration in 2006, both in the University of Castilla-La Macha. Her thesis dealt with logistic models to predict the business failure in different phases of difficulty. She has published in national and international journals such as Innovar, African Journal of Business Management, Revista Europea de Dirección y Economía de la Empresa, and Strategy \& Management Business Review.

Regino Banegas Ochovo is a Professor of Accounting and Finance at the University of Castilla-La Mancha (UCLM). He completed his degree in Economy and Management in 1984 at the Complutense University of Madrid and earned his Ph.D. in Economy and Management in 1996 at the University of Castilla-La Macha. He is Deputy Director of the Department of Business Administration and has published in national and international journals such as Innovar, African Journal of Business Management, Revista Española de Financiación y Contabilidad, Revista Europea de Dirección y Economía de la Empresa, and Strategy \& Management Business Review.

Alba María Priego de la Cruz is a Lecturer in the Departament of Business Administration in the Faculty of Social Sciences at the Universidad of Castilla-La Mancha in Spain. She teaches courses in cost and financial accounting for undergraduate students. She received her Ph.D. in Financial Economics and Accounting in 2012 from the University of Castilla-La Macha. Her main research interests are in financial analysis of business failure. Her publications have appeared in journals such as Academia Revista Latinoamericana de Administración, Pecunia, Revista de Contabilidad y Dirección, and Strategy \& Management Business Review. 


\section{REFERENCES}

1. Altman, E. (1984). The sucess of business failure prediction models. An international survey. Journal of Banking and Finance, 8, 171-198.

2. $\quad$ Argenti, J. (1976). Corporate planning and corporate collapse. Lon Range Planning, 9(6), 12-17.

3. Beaver, W. (1966). Financial ratios as predictors of failure. Journal of Accounting Research, Supplement, 71-111.

4. Campbell, N., Heriot, K., Jauregui, A., \& Mitchell, D. (2012). Which state policies lead to US firm exits? Analysis with the economic feedom index. Journal of Small Business Management, 50(1), 87-104.

5. Chen, J. \& Williams, M. (1999). The determinants of business failure in the US low-technology and hightechnology industries. Applied Economics, 31, 1551-1563.

6. Choi, J. \& Wang, H. (2009). Stakeholder relations and the persistence of corporate financial performance. Strategic Management Journal, 30, 895-907.

7. Davis, J. \& Newstrom (1999). Comportamiento humano en el trabajo. 10 ${ }^{a}$ Edición. México: McGraw-Hill.

8. Dutton, J., Dukerich, J., \& Harquail, C. (1994). Organizational images and member identifications. Administrative Science Quarterly, 39, 239-263.

9. Fernández, J. (1997). Deontología del empresario. En: Ética y Empresa: Una visión multidisciplinar. (pp. 115-137). Madrid: Fundación Argentaria y Visor.

10. Greenhalgh, L. (1983). Managing the job insecurity crisis. Human Resource Management, 22, 431-444.

11. Hackman, J. \& Oldham, J. (1980). Job redesign. Reading. S.l.:MA Addison-Wesley.

12. Hardy, C. (1987). Investing in retrenchment: Avoiding the hidden costs. California Management Review, 29 (4), 111-125.

13. Hendriks, W. (2008). The relation between employee relations and shareholder value in the context of changing corporate governance: Can Anglo-Saxon corporate governance practices harm employees? Master Thesis. Universiteit Maastricht. Faculty of Economics and Business Administration.

14. Iglesias, C., Llorente, R., \& Dueñas, D. (2011). Calidad del empleo y satisfacción laboral en las regiones españolas. Un estudio con especial referencia a la Comunidad de Madrid. Investigaciones Regionales, 19, 25-49.

15. Jones, T. (1995). Instrumental Stakeholder Theory: A synthesis of Ethics and Economics. Academy of Management Review, 20(2), 404-437.

16. Kane, G., Velury, U., \& Ruf, B. (2005). Employee relations and the likehood of occurrence of corporate financial distress. Journal of Business Finance \& Accounting, 32(5-6), 1083-1105.

17. Keasey, K. \& Watson, R. (1991). Financial distress prediction models. A review of their usefulness. British Journal of Management, 2(2), 89-102.

18. Liu, J. (2004). Macroeconomic Determinants of Corporate Failures: Evidence from the UK. Applied Economics, 36, 939-945.

19. Ooghe, H. \& Waeyaert, N. (2004). Oorzaken van failin: literaturoverzicht en conceptueel verklaringsmodel. Economischen Social Tijdschrift, 57(4), 367-393.

20. Organ, D. \& Ryan, K. (1995). A Meta-Analytic Review of Attitudinal and Dispositional Predictors of

21. Pajunen, K., 2006. Stakeholder Influences in Organizational Survival. Journal of Management Studies, 43(6), 1261-1288.

22. Ruf, B., Muralidhar, K., Brown, R., Janney, J., \& Paul, K. (2001). An empirical investigation of the relationship between change in corporate social performance and financial performance: a stakeholder theory perspective. Journal of Business Ethics, 32, 143-156.

23. Sutton, R. I., Eisenhardt, K. M., \& Jucker, J. V. (1986). Managing organizational decline. Organizational Dynamics, 14 (4), 17-29.

24. Zatzick, D. C. \& Iverson, R. D. (2006). High-involvement management and workforce reduction: Competitive advantage or disadvantage?. Academy of Management Journal, 48 (5), 990-1015. 
NOTES 